\title{
Notes on the orchids of Bali, Indonesia: six new species records
}

\author{
M.B. Atmaja \& I.G. Tirta \\ Bali Botanic Garden - Indonesian Institute of Sciences (LIPI) \\ Candikuning, Baturiti, Tabanan 82191, Bali, Indonesia \\ muha175@lipi.go.id
}

\begin{abstract}
Six species of orchids are reported as new records for Bali. Two of the species were found to be growing wild in Bali Botanic Garden, which was formerly a part of the Batukahu Nature Reserve, while the rest were collected from other forests in Bali. The six newly recorded species are Bulbophyllum apodum Hook.f., Ceratostylis longipedunculata J.J.Sm., Dendrobium arcuatum J.J.Sm., Dendrobium connatum (Blume) Lindl., Habenaria reflexa Blume and Taeniophyllum hirtum Blume. Brief descriptions and photographs are provided.
\end{abstract}

Keywords. Epidendroideae, Lesser Sunda Islands, Orchidaceae, Orchidoideae, Wallace's Line

\section{Introduction}

There are increasing threats to orchids in their natural habitats, mainly due to human activities such as habitat destruction and over-collecting (IUCN/SSC Orchid Specialist Group, 1996; Lestari \& Santoso, 2011; Barman \& Devadas, 2013), or as a consequence of natural disasters related to climate change (Seaton et al., 2010; Barman \& Devadas, 2013). Nevertheless, new records of orchid species for Bali are being found. Compared to neighbouring Java, the flora of Bali is still poorly documented (Van Balgooy \& Widjaja, 2014).

Seven orchid species have recently been newly recorded for Bali: Sulistiarini et al. (2016) recorded Calanthe zollingeri Rchb.f., Plocoglottis plicata (Roxb.) Omerod, Podochilus serpyllifolius (Blume) Lindl., Styloglossum speciosum (Blume) T.Yukawa \& P.J.Cribb and Vanilla albida Blume, while Wibowo et al. $(2015,2016)$ added Thrixspermum obtusum (Blume) Rchb.f. and T. squarrosum J.J.Sm. Thrixspermum obtusum was also a new record for Sumatra and Nusa Tenggara.

Under the Geographical Scheme for Recording Plant Distributions (Brummitt, 2001), the island of Bali is encoded as LSI-BA and grouped into the Lesser Sunda Islands. However, the island is closer to the east end of Java (JAW-OO) than to Lombok (LSI-LS). The shortest distance from Bali to Java is approximately $2.5 \mathrm{~km}$ (from Bali Barat National Park to Kalipuro), while the shortest distance between Bali and Lombok (from Sengkidu to Batu Putih) is $>35 \mathrm{~km}$. Wallace (1869) grouped Bali with Java into the Indo-Malayan Region based on geographical, zoological and ethnological similarities. Lombok, in contrast, was grouped with Timor, east of what became known as Wallace's Line. Five of the six species of orchids which are newly recorded from Bali are known to occur in Java but not in Lombok. 
The new records are now cultivated at Bali Botanic Garden (BBG) which is located in Tabanan regency, $60 \mathrm{~km}$ north of Denpasar. The herbarium specimens are deposited in Tabanan Herbarium Hortus Botanicus Baliense (THBB). Two of the species were found to be growing wild inside the botanic garden which was formerly part of the Batukahu Nature Reserve. The other four species were collected from various forests in other parts of Bali. Habenaria reflexa Blume belongs to subfamily Orchidoideae, the others to subfamily Epidendroideae (Chase et al., 2015).

Based on data from the Statistics of Bali Province (continuously updated), the island of Bali has 1,325.28 square $\mathrm{km}$ of forest, which is about 23 percent of the total land area of the island. With such large forested areas at various elevations, it is certain that not all of these forests have yet been thoroughly explored even though there is a long history of botanical exploration in Bali. Therefore, more new orchid records are to be expected in the future. Moreover, certain species, such as those that are seasonally dormant, ephemeral, leafless or small can be easily overlooked during most the year. Only sustained exploration effort will bring these to light.

\section{New records}

1. Bulbophyllum apodum Hook.f., Fl. Brit. India 5: 766 (1890). (Fig. 1A-B)

Frequently found growing together with Bulbophyllum gibbosum (Blume) Lindl., this BBG native species was previously misidentified as Bulbophyllum odoratum (Blume) Lindl. (Lugrayasa \& Mudiana, 2000; Tirta \& Sutomo, 2014). Common in a fairly open area inside the garden at c. $1300 \mathrm{~m}$ asl., it grows on almost every large branching tree such as Bischofia javanica Blume, Casuarina junghuhniana Miq., Dacrycarpus imbricatus (Blume) de Laub., Pinus thunbergii Parl. and Prunus cerasoides Buch.Ham. ex D.Don. Both Bulbophyllum apodum and B. gibbosum flower in February for about one month, and as they can grow together on the same tree, it is difficult to distinguish these two species without binoculars. The leaves of Bulbophyllum apodum are longer than those of $B$. gibbosum, about $25-30 \mathrm{~cm}$ and $20-25 \mathrm{~cm}$ respectively, and $B$. apodum has a $40 \mathrm{~cm}$ long inflorescence, which emerges from the rhizome, with 4-6 peduncle scales, bearing more than 50 pale yellow-coloured flowers, whilst in $B$. gibbosum the inflorescence is shorter, appearing erect from the base of the leaf with a single peduncle scale, bearing up to 40 cream-coloured, yellow-lipped and scented flowers.

Distribution. China (South-Central), Northeast India, Nicobar Islands, Myanmar, Thailand, Laos, Vietnam, Peninsular Malaysia, Sumatra, Borneo, Java, Lesser Sunda Islands, Sulawesi, Maluku, Philippines, New Guinea, Solomon Islands, southwestern Pacific islands (Vermeulen, 1991; Govaerts et al., continuously updated).

Specimen examined. INDONESIA: Bali: Tabanan Regency, Baturiti District, Candikuning Village, c. 1300 m, 7 Feb 2018, MBA 302 (THBB). 


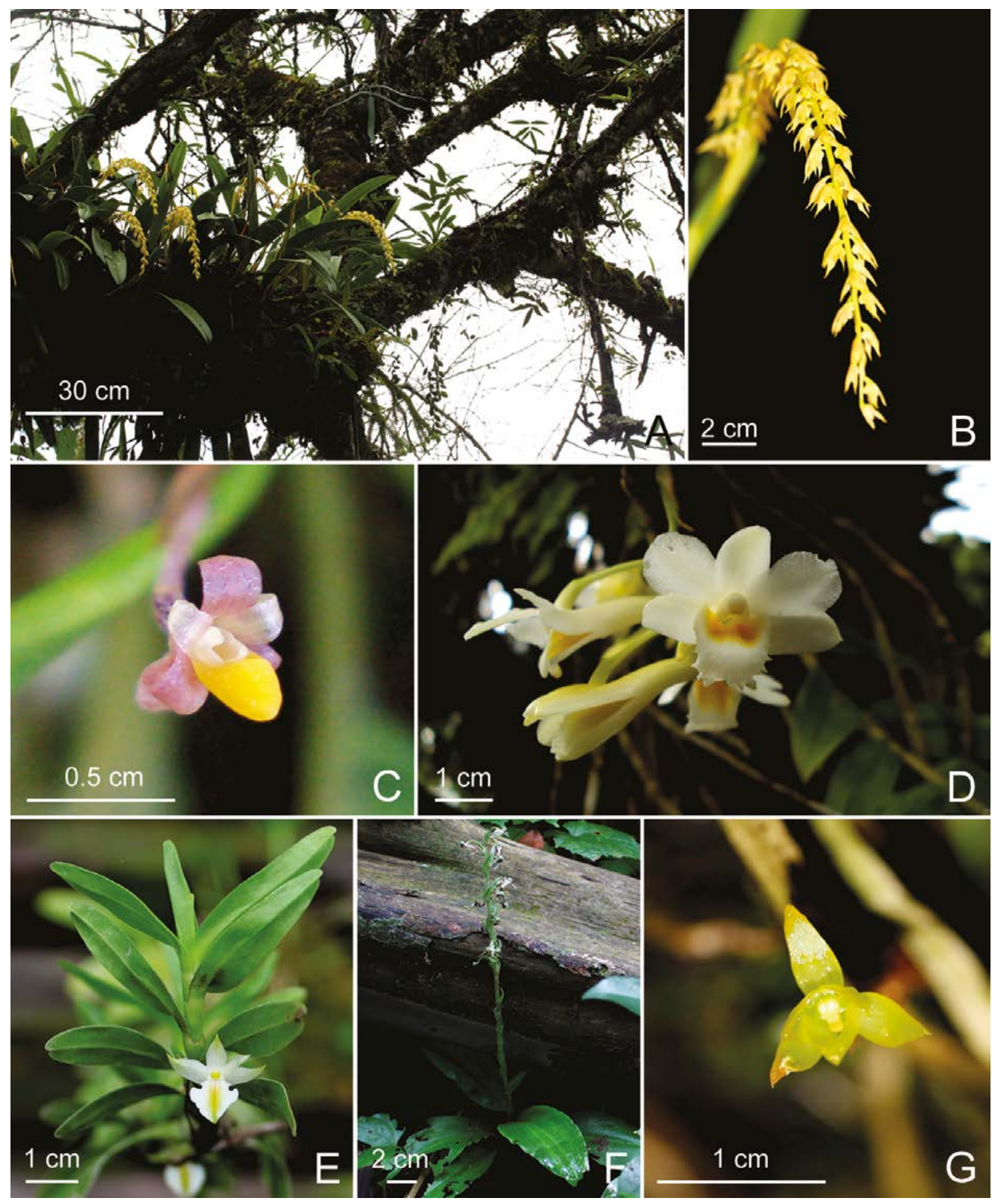

Fig. 1. A \& B. Bulbophyllum apodum Hook.f. A. Habit. B. Inflorescence. C. Ceratostylis longipedunculata J.J.Sm. D. Dendrodium arcuatum J.J.Sm. E. Dendrobium connatum (Blume) Lindl. F. Habenaria reflexa Blume. G. Taeniophyllym hirtum Blume. A, B, \& G, in situ in Bali Botanic Garden; C, D \& E cultivated in Bali Botanic Garden; F, in situ in Taman Nasional Bali Barat. (Photos: A-B \& F-G, M.B. Atmaja; C-E, A.R.U. Wibowo). 
2. Ceratostylis longipedunculata J.J.Sm., Meded. Rijks-Herb. 53: 6 (1925). (Fig. 1C)

This sympodial epiphyte was previously recorded only from Mount Rinjani on the island of Lombok. The Bali specimen was collected by I Gede Tirta from Tabanan regency in September 2012. It was found living on a Platea excelsa Blume tree at c. $1540 \mathrm{~m}$ asl. Stems emerge from the rhizome, are terete, bear 1 leaf and 1-2 terminal flower(s), and are as long as the leaves. Leaves 70-85 $\times 6 \mathrm{~mm}$, flat, thick, with obtuse or emarginate apex. Flowers $5 \mathrm{~mm}$ diam., pedicel about $10 \mathrm{~mm}$ long, ovary approximately $5 \mathrm{~mm}$ long, sepals and petals white-purplish, lip white at the base and yellow-coloured from the centre towards the apex. Flowering in January, May and October in BBG.

Distribution. Lombok (Creuwels, continuously updated a,b,c).

Specimen examined. INDONESIA: Bali: Tabanan Regency, Baturiti District, Pengelengan Hill, c. 1540 m, 13 Sep 2012, GT 3146/HK 1644 (THBB [also living collection in BBG, E2012090007]).

3. Dendrobium arcuatum J.J.Sm., Orch. Java 357 (1905). (Fig. 1D)

Found by I Gede Tirta in Buleleng regency in November 2003. Epiphytic in light shade on a Syzygium polycephalum (Miq.) Merr. \& L.M.Perry tree at an elevation of $900 \mathrm{~m}$ asl. Stems horizontal or hanging, bearing leaves at intervals of $2 \mathrm{~cm}$ or more. Leaves $9-10 \times 3 \mathrm{~cm}$, thin, lanceolate with attenuate apex. More than one inflorescence emerges near the apical part of the stem, each inflorescence bearing 4 or more slightly yellowish white flowers. Flowers c. $3 \mathrm{~cm}$ diam. with a mentum twice as long as the dorsal sepal, the lip is yellow at the base and white at the tip. Flowering around February to April in BBG.

Distribution. Borneo, Java (Comber, 1990; Govaerts et al., continuously updated).

Specimen examined. INDONESIA: Bali: Buleleng Regency, Busungbiu District, Sepang Forest, c. 900 m, 23 Nov 2003, GT 1729/HK 1643 (THBB [also living collection in BBG, E20031223]).

4. Dendrobium connatum (Blume) Lindl., Gen. Sp. Orchid. P1. 89 (1830). (Fig. 1E)

In June 2015, Wenni Setyo Lestari found this orchid in Jembrana regency. Located at an elevation of c. $530 \mathrm{~m}$ asl, it grows as an epiphyte on a Ficus L. tree. The stems can grow up to $50 \mathrm{~cm}$ long, covered by alternate leaves with overlapping sheaths throughout its length. Leaves lanceolate, around $2 \mathrm{~cm}$ long, unevenly emarginate. Inflorescence 1-flowered, supra-axillary, flower about $1.5 \mathrm{~cm}$ diam. Sepals lanceolate with acuminate apex, petals smaller, both white-coloured and green-veined. Lip rounded, slightly apiculate, with two small side-lobes at the base, white-coloured, yellow warts along its centre line. The BBG specimen flowers in August. 
Distribution. Thailand, Peninsular Malaysia, Sumatra, Borneo, Java, Maluku (Comber, 1990; Govaerts et al., continuously updated).

Specimen examined. INDONESIA: Bali: Jembrana Regency, Mendoyo District, Pasatan Forest, c. 530 m, 11 Jun 2015, WN 231 (THBB [also living collection in BBG, E2015060296]).

5. Habenaria reflexa Blume, Bijdr. Fl. Ned. Ind.: 403 (1825). (Fig. 1F)

Ni Putu Sri Asih collected this terrestrial orchid in Jembrana regency in April 2018. The forest is a part of Bali Barat National Park. Found after flowering at an elevation of c. $160 \mathrm{~m}$ asl on humus-rich soil with a thin layer of leaf litter, near dry water channels. The plants have a small (2.5-3 cm long) and slightly fusiform underground tuber, bearing 4-5 leaves just above the ground. Leaves lanceolate, acute, c. $17 \times 5 \mathrm{~cm}$, margin slightly undulate, with indistinctly reticulate venation. Inflorescence with 6-9 erect, lanceolate, acuminate peduncle scales; bearing more than 10 flowers. Flowers pale green with lanceolate and acuminate floral bracts, lateral sepals white, petals undivided. The lip has three linear lobes, the mid-lobe longer than the side lobes and sigmoid. Spur long and turned $180^{\circ}$ towards the front.

Distribution. Indian-Subcontinent (East Himalaya), Thailand, Laos, Vietnam, Peninsular Malaysia, Sumatra, Java (Comber, 1990; Govaerts et al., continuously updated).

Specimen examined. INDONESIA: Bali: Jembrana Regency, Melaya District, Palarejo Forest, c. 160 m, 20 Apr 2018, PSA 314 (THBB [also living collection in BBG, E2018050131]).

6. Taeniophyllum hirtum Blume, Bijdr. Fl. Ned. Ind. 356 (1825). (Fig. 1G)

Unlike the relatively common Bulbophyllum apodum in the BBG, this leafless epiphytic orchid is uncommon inside BBG. The plants are attached to branches of a Schima wallichii (DC.) Korth. tree in an area sheltered from the sun and with a high humidity. We also found it attached to the trunk of a Rhododendron L. spp. planted near this Schima wallichii tree. There is an artificial pond near the host trees. Vigorous plants have pale green to dark green and slightly flat roots. Most of the roots are hanging and only a few are attached to the bark of the host tree. The brown, finely muricate inflorescence is 3-6 cm long, carrying at least 5 flowers that open sequentially from the base to the tip. This species flowers from the beginning of the rainy season to the early dry season. Flowers are c. $1 \mathrm{~cm}$ diam., greenish-yellow, sepals and petals lanceolate, petals slightly smaller than sepals, lip thick with edges folded inwards, spur ellipsoid. Fruits cylindrical, $1.5-2 \mathrm{~cm}$ long.

Distribution. Java, Borneo (Comber, 1990; Govaerts et al., continuously updated). 
Specimen examined. INDONESIA: Bali: Bali Island, Tabanan Regency, Baturiti District, Candikuning Village, c. 1300 m, 18 Jul 2019 , MBA 304 (THBB).

ACKNOWLEDGEMENTS. We thank the Balai Taman Nasional Bali Barat, KPH Bali Barat and KPH Bali Selatan for issuing permits to the BBG exploration teams to undertake expeditions and collect orchids from forested areas. We are also grateful to the BBG exploration teams who are mentioned in the text. We would like to thank Aninda Retno Utami Wibowo for photographs. We also express our gratitude to Luh Sarini, I Putu Suparta, I Ketut Toya, I Gede Ardika who are taking care of the orchid collections in BBG and I Gusti Made Sudirga who is handling the herbarium vouchers in THBB. The BBG botanical expeditions were supported by the DIPA budget for the Exploration of Flora of the Eastern Indonesia programme.

\section{References}

Barman, D. \& Devadas, R. (2013). Climate change on orchid population and conservation strategies: a review. J. Crop Weed 9(2): 1-12.

Brummitt, R.K. (2001). World geographical scheme for recording plant distributions, edition 2. Pittsburgh: Hunt Institute for Botanical Documentation Carnegie Mellon University.

Chase, M.W., Cameron, K.M., Freudenstein, J.V., Pridgeon, A.M., Salazar, G., Berg, C.V.D. \& Schuiteman, A. (2015). An updated classification of Orchidaceae. Bot. J. Linn. Soc. 177: $151-174$.

Comber, J.B. (1990). Orchids of Java. Surrey: Bentham-Moxon Trust, Royal Botanic Gardens Kew.

Creuwels, J. (continuously updated a). Occurrence dataset. Naturalis Biodiversity Center (NL) - Botany. https://www.gbif.org/occurrence/1140290986. Accessed 20 Jul. 2018.

Creuwels, J. (continuously updated b). Occurrence dataset. Naturalis Biodiversity Center (NL) - Botany. https://www.gbif.org/occurrence/1138264624. Accessed 20 Jul. 2018.

Creuwels, J. (continuously updated c). Occurrence dataset. Naturalis Biodiversity Center (NL) - Botany. https://www.gbif.org/occurrence/1141253195. Accessed 20 Jul. 2018.

Govaerts, R., Bernet, P., Kratochvil, K., Gerlach, G., Carr, G., Alrich, P., Pridgeon, A.M., Pfahl, J., Campacci, M.A., Baptista, D.H., Tigges, H., Shaw, J., Cribb, P., George, A., Kreuz, K. \& Wood. J. (continuously updated). World Checklist of Orchidaceae. Royal Botanic Gardens, Kew. http://wcsp.science.kew.org/. Accessed 19 Jul. 2018.

IUCN/SSC Orchid Specialist Group (1996). Orchids - Status Survey and Conservation Action Plan. Gland and Cambridge: IUCN.

Lestari, D.A. \& Santoso, W. (2011). Inventory and habitat study of orchids species in Lamedai Nature Reserve, Kolaka, Southeast Sulawesi. Biodiversitas 12(1): 28-33.

Lugrayasa, I.N. \& Mudiana, D. (2000). Anggrek Bulbophyllum alam di kebun raya Eka Karya Bali. BioSMART 2(2): 15-20.

Seaton, P.T., Hu, H., Perner, H. \& Pritchard, H.W. (2010). Ex situ conservation of orchids in a warming world. Bot. Rev. 76: 193-203.

Statistics of Bali Province (continuously updated). Area of forest by regency/city and its function in Bali Province 2017. BPS-Statistics Indonesia. https://bali.bps.go.id/ statictable/2018/04/11/75/luas-kawasan-hutan-menurut-kabupaten-dan-fungsinya-diprovinsi-bali-2016.html. Accessed 20 Jul. 2018. 
Sulistiarini, D., Arifiani, D. \& Santika, Y. (2016). New records of Orchidaceae from Bali, Indonesia. Gard. Bull. Singapore 68(1): 87-95.

Tirta, I.G. \& Sutomo. (2014). Inventory of epiphyte orchid at Eka Karya Bali botanic garden. Widyariset 17(2): 245-250.

Van Balgooy, M.M.J. \& Widjaja, E.A. (2014). Flora of Bali: a provisional checklist. Reinwardtia 14(1): 219-221.

Vermeulen, J.J. (1991). Orchids of Borneo, vol. 2, Bulbophyllum. Bentham-Moxon Trust, Royal Botanic Gardens Kew.

Wallace, A.R. (1869). The Malay archipelago: the land of the orang-utan and the bird of paradise, a narrative of travel with studies of man and nature. London and Bungay: Richard Clay and Sons, Limited.

Wibowo, A.R.U., Tirta, I.G., Juswara, L.S. \& Kocyan, A. (2015). New record suggests an expanded distribution area of Thrixspermum squarrosum J.J.Sm. Malesian Orchid J. 16: 79-82.

Wibowo, A.R.U., Atmaja, M.B., Peneng, I.N. \& Tirta, I.G. (2016). An expanded distribution area for Thrixspermum obtusum (Blume) Rchb.f. in Indonesia. Malesian Orchid J. 18: 75-78. 
